\title{
A case of familial dysalbuminemic hyperthyroxinemia (FDH) in Japan: FDH as a possible differential diagnosis of syndrome of inappropriate secretion of thyroid-stimulating hormone (SITSH)
} \author{
Kiminori Sugino ${ }^{2)}$, Hiroshi Itoh ${ }^{1)}$ and Koichi Ito ${ }^{2)}$ \\ 1) Department of Internal Medicine, Keio University School of Medicine, Tokyo 160-8582, Japan \\ 2) Ito Hospital, Tokyo 150-8308, Japan \\ 3) Roche Diagnostics K.K., Tokyo 105-0014, Japan
}

Sakiko Kobayashi ${ }^{1), 2)}$, Jaeduk Yoshimura $\mathrm{Noh}^{2)}$, Taeko Shimizu ${ }^{2)}$, Tomoaki Sato ${ }^{3)}$, Isao Kurihara ${ }^{1)}$,

\begin{abstract}
Familial dysalbuminemic hyperthyroxinemia (FDH) is an autosomal dominant condition and is the most commonly inherited euthyroid hyperthyroxinemia in Caucasians. However, it is extremely rare in Asian populations. A 30-year-old Japanese woman, who was incidentally found to have apparent thyroid dysfunction, was admitted to our hospital in 2004. She had extremely elevated serum free thyroxine $\left(\mathrm{FT}_{4}\right)$, moderately elevated free triiodothyronine $\left(\mathrm{FT}_{3}\right)$, and normal thyroid-stimulating hormone (TSH). Clinical thyroid examination revealed no abnormalities other than small goiter. Anti-thyroglobulin antibody titer was positive, but titers of other anti-thyroid antibodies, including antithyroid peroxidase antibody, TSH receptor antibodies, and thyroid-stimulating antibody, were negative. Levels of $\mathrm{FT}_{3}, \mathrm{FT}_{4}$, and TSH were similar when measured by three different laboratory kits, and $\mathrm{FT}_{4}$ was still high when measured by equilibrium dialysis. By affinity chromatography, $\mathrm{FT}_{4}, \mathrm{TT}_{4}$, and albumin were extracted to the same fraction, and the levels of $\mathrm{FT}_{4}$ and $\mathrm{TT}_{4}$ were extremely high. By combination of reversed phase liquid chromatography and mass spectrometry techniques, the amino acid sequence of human serum albumin was determined. The patient was found to be a heterozygote for p.R218P mutation in the gene for human serum albumin and was diagnosed as FDH. This patient, who harbored the p.R218P mutation in the albumin gene, is the fifth case report of FDH in Japan. This condition is characterized by extremely high serum $\mathrm{FT}_{4}$ and moderately high serum $\mathrm{FT}_{3}$ levels. Although rare, $\mathrm{FDH}$ should be considered in the differential diagnosis for syndrome of inappropriate secretion of TSH (SITSH) in Japan.
\end{abstract}

Key words: Hyperthyroxinemia, Albumin, Familial, Thyroid, Syndrome of inappropriate secretion of TSH

FAMILIAL DYSALBUMINEMIC HYPERTHYROXINEMIA (FDH) is a familial autosomal dominant disorder caused by abnormal albumin that has an increased affinity for thyroxine $\left(\mathrm{T}_{4}\right)$, resulting in elevated serum total $\mathrm{T}_{4}\left(\mathrm{TT}_{4}\right)$ concentration but normal thyrotropin levels. FDH is the most common cause of inherited euthyroid hyperthyroxinemia in Caucasian populations, which was first reported in 1979 [1]. In 1994, a missense mutation in the albumin gene (p.R218H; a replacement of arginine 218

Submitted Mar. 10, 2016; Accepted Oct. 26, 2016 as EJ16-0135 Released online in J-STAGE as advance publication Nov. 30, 2016 Correspondence to: Sakiko Kobayashi, M.D., Ph.D., Department of Internal Medicine, Keio University School of Medicine, 35 Shinanomachi, Shinjuku-ku, Tokyo 160-8582, Japan.

E-mail: s-k815@z8.keio.jp

Abbreviations: FDH, familial dysalbuminemic hyperthyroxinemia; with histidine) was reported in patients with FDH [2, 3]. Another missense mutation in the same codon of the albumin gene (p.R218P; a replacement of arginine 218 with proline) was identified in a Japanese family [4] and a Swiss family [5]. The phenotype of patients with the p.R218P mutation of the albumin gene is characterized by high serum $\mathrm{TT}_{4}$ levels (more than 10-fold the normal upper limit) when compared with those of patients with the p.R218H mutation (a two- to three-fold increase). While most previous

SITSH, syndrome of inappropriate secretion of thyroid-stimulating hormone; $\mathrm{FT}_{4}$, free thyroxine; $\mathrm{TT}_{4}$, total thyroxine; $\mathrm{FT}_{3}$, free triiodothyronine; $\mathrm{TT}_{3}$, total triiodothyronine; $\operatorname{TrT}_{3}$, total reverse triiodothyronine; TBG, thyroxin binding globulin; RIA, radioimmunoassay; TRAb, TSH receptor antibody; TSAb, Thyroid-stimulating antibody; HAMA, human anti-mouse monoclonal antibody thyroid-stimulating hormone. 
studies have demonstrated that serum $\mathrm{FT}_{4}$ measured by equilibrium dialysis/radioimmunoassay (RIA) was normal in patients with p.R $218 \mathrm{H}$ mutation, serum $\mathrm{FT}_{4}$ levels were elevated in the patients with p.R218P mutation. A third albumin mutation, p.L66P (a replacement of leucine 66 with proline), was identified in a Thai family and is characterized by predominant elevation of the triiodothyronine $\left(\mathrm{T}_{3}\right)$ concentration [6]. In 2014, two novel mutations in the albumin gene were reported. One was the p.R218S mutation (a replacement of arginine 218 with serine) that was identified in a Bangladeshi family, which was characterized by a nine-fold increase in serum $\mathrm{TT}_{4}$ and a two-fold increase in serum total reverse $T_{3}$ when compared with patients with normal albumin [7]. The other was the p.R222I mutation (a replacement of arginine 222 with isoleucine) that was found in three African (Somali) subjects and in one East European (Croatian) family. $\mathrm{FT}_{4}$ measurements tend to be higher in the one-step platform than in the two-step platform, and this pattern resembled the differential of susceptibility of such assays with R218H FDH sera [8]. Reverse $\mathrm{T}_{3}$ concentrations were 40- to 70 - fold elevated when compared with the normal upper limit [9]. Characteristics of the described mutations are summarized in Table 1. The present report is the fifth report of FDH caused by the p.R218P mutation in the albumin gene in Japan.

\section{Patient and Methods}

\section{Patient}

A 30-year-old Japanese woman, who was incidentally found to have thyroid dysfunction at a mental health clinic in which she was treated for postpartum depression, was referred to our hospital for evaluation in 2004. She had extremely elevated serum $\mathrm{FT}_{4}(>7.77$ $\mathrm{ng} / \mathrm{dL}$; reference range, $0.8-1.6 \mathrm{ng} / \mathrm{dL}$ ), relatively elevated free triiodothyronine $\left(\mathrm{FT}_{3}\right)(7.8 \mathrm{pg} / \mathrm{mL}$; reference range, 2.2-4.3 $\mathrm{pg} / \mathrm{mL}$ ) and normal thyroid-stimulating hormone (TSH) $(1.2 \mu \mathrm{U} / \mathrm{mL}$; reference range, 0.2-4.5 $\mu \mathrm{U} / \mathrm{mL}$ ). Clinical thyroid examination revealed no abnormalities other than a small goiter. She was clinically considered to be euthyroid. She was born in the Kyushu District of Japan, and her father was diagnosed with "thyroid disease", but the precise diagnosis was not known.

\section{Thyroid function tests}

Serum $\mathrm{FT}_{3}, \mathrm{FT}_{4}$, and $\mathrm{TSH}$ levels were measured using the following commercial kits: ECLusys $\mathrm{FT}_{4}$, $\mathrm{FT}_{3}$, and TSH assays (Roche Diagnostics $\mathrm{GmbH}$, Mannheim, Germany), ARCHITECT (Dainabot Co., Ltd., Tokyo, Japan), and Lumipulse (Fujirebio, Inc., Tokyo, Japan). Serum $\mathrm{FT}_{4}$ levels were measured by RIA after equilibrium dialysis using a kit supplied by Nicholas Institute Diagnostics (San Juan Capistrano, CA). Thyroxin binding globulin (TBG) was measured using a RIA kit (Nihon Schering K.K., Osaka, Japan). Antithyroglobulin antibody (TgAb) and antithyroid peroxidase antibody (TPOAb) were measured by RIA using kits provided by Cosmic Corp. (Tokyo, Japan). TSH receptor antibody (TRAb) was measured with TRAb computed tomography (Cosmic Corp, Tokyo, Japan). Thyroid-stimulating antibody (TSAb) was measured with a TSAb kit "Yamasa" provided by Yamasa Shoyu Co., Ltd. (Chiba, Japan).

Table 1 Various mutations of the albumin gene that cause hyperthyroxinemia and/or hypertriiodothyroxinemia and their thyroid functions

\begin{tabular}{|c|c|c|c|c|c|}
\hline & \multicolumn{5}{|c|}{ Mutation } \\
\hline & $\mathrm{R} 218 \mathrm{H}$ & R218P & R218S & R222I & L66P \\
\hline$\overline{\mathrm{FT}_{4}}$ & $\uparrow^{* 1}$ & $\overline{\uparrow \uparrow}$ & $\uparrow$ & $\uparrow^{* 1}$ & \\
\hline $\mathrm{TT}_{4}$ & 2- to 3 -fold $* 2$ & 11- to 17 -fold $* 2$ & 9 -fold $* 3$ & & 1.0 -fold $* 3$ \\
\hline $\mathrm{TT}_{3}$ & 1.1 -fold $* 2$ & 2 -fold $* 3$ & 1.3 -fold $* 3$ & $\uparrow \rightarrow * 4$ & 2.6 -fold $* 3$ \\
\hline $\mathrm{TrT}_{3}$ & 1.5 -fold $* 3$ & 6.1 -fold $* 3$ & 2.6-fold $* 3$ & 40 - to 70 -fold $* 5$ & 1.0 -fold $* 3$ \\
\hline Region *3 & $\begin{array}{l}\text { Caucasian } \\
\text { (Portuguese and } \\
\text { Hispanic ancestry) }\end{array}$ & $\begin{array}{l}\text { Japanese } \\
\text { Swiss }\end{array}$ & Bangladeshi & $\begin{array}{l}\text { Somali } \\
\text { Croatian }\end{array}$ & Thai \\
\hline
\end{tabular}

\footnotetext{
${ }^{* 1}$ Grossly elevated by standard direct (antibody-based) assays, however, exhibit different values by different assay kits.

*2 Measured by RIA, compared to normal upper limit.

*3 Measured by RIA, compared to normal mean value.

${ }^{* 4}$ Measured by tandem mass spectrometry, compared to normal upper limit.

*5 Measured by tandem mass spectrometry, compared to normal upper limit.

$\mathrm{FT}_{4}$, free thyroxine; RIA, radioimmunoassay; $\mathrm{TT}_{4}$, total thyroxine; $\mathrm{TT}_{3}$, total triiodothyronine; $\mathrm{TrT}_{3}$, total reverse triiodothyronine.
} 
Measurement of TSH with human anti-mouse monoclonal antibody (HAMA) treatment

To exclude the possible effect of HAMA for the measurement of TSH, MAK33-igg1-fad1-Poly (Roche Diagnostics GmbH, Mannheim, Germany) was added to the sample at a concentration of $500 \mu \mathrm{g} / \mathrm{mL}$, reacted at room temperature for 30 minutes, then TSH was measured with the ECLusys TSH assay kit (Roche Diagnostics GmbH, Mannheim, Germany).

\section{Assay to evaluate the effect of antibodies in the serum}

To check the possible effect of anti- $\mathrm{T}_{3}$ or anti- $\mathrm{T}_{4}$ antibodies, protein A (Roche Applied Science, Tokyo, Japan) was added to the serum, and the solution was mixed. After centrifugation, $\mathrm{FT}_{4}$ and $\mathrm{TT}_{4}$ in the supernatant were measured with ECLusys $\mathrm{FT}_{4}$ and $\mathrm{T}_{4}$.

\section{Affinity chromatography}

Affinity chromatography was performed using a size-exclusion chromatography column (PROTEIN KW-804 [Shodex, Tokyo, Japan] with buffer (50 $\mathrm{mM}$ Tris-HCL, $150 \mathrm{mM} \mathrm{NaCl}, \mathrm{pH}$ 7.2) with a flow rate $0.75 \mathrm{~mL} / \mathrm{min}$ and a fraction of 30 seconds/tube. Concentrations of $\mathrm{FT}_{4}, \mathrm{TT}_{4}$, albumin, and TBG in each fraction were measured. $\mathrm{FT}_{4}$ and $\mathrm{T}_{4}$ were measured by ECLusys $\mathrm{FT}_{4}$ or $\mathrm{T}_{4}$ (Roche Diagnostics $\mathrm{GmbH}$, Mannheim, Germany).

\section{Reversed phase liquid chromatography, followed by mass spectrometry}

Samples were denatured in denaturation buffer $(6 \mathrm{M}$ guanidinium $\mathrm{HCl} / 0.1 \mathrm{M}$ Tris/ 1mM EDTA pH8.3), reduced (Jodasetamide $9.3 \mathrm{mg} / \mathrm{dL}, 100 \mathrm{mM}$ Tris- $\mathrm{HCl}$, pH8.5) and digested by trypsin in digestion buffer (100mM Tris- $\mathrm{HCl}, \mathrm{pH} 8.5)$. Reversed phase liquid chromatography was performed using a high-performance liquid chromatography column (Vydac C18, Grace Vydac, Hesperia, California, USA) with eluent at a 60 -min gradient from $0.025 \%$ trifluoroacetic acid in water to $0.025 \%$ trifluoroacetic acid in acetonitrile. Amino acid sequencing was performed using the mass spectrometry technique by Thermo Linier trap Quadrupole (LTQ) (Thermo Fisher Scientific, Inc., Waltham, Massachusetts, USA).

\section{Results}

Thyroid function was measured again with the same ECLusys $\mathrm{FT}_{4}, \mathrm{FT}_{3}$, and TSH assays, and the results were similar $\left(\mathrm{FT}_{4}>7.77 \mathrm{ng} / \mathrm{dL}, \mathrm{FT}_{3} 8.2 \mathrm{pg} / \mathrm{mL}\right.$, and TSH $3.74 \mu \mathrm{U} / \mathrm{mL}$ ). When the levels of $\mathrm{FT}_{3}, \mathrm{FT}_{4}$ and TSH were measured by three different laboratory kits, the results were similar (Table 2). $\mathrm{FT}_{4}$ was still high when measured with the equilibrium dialysis method. $\mathrm{TgAb}$ was negative $(1.7 \mathrm{U} / \mathrm{mL}$; reference range $\leq 2.6 \mathrm{U} /$ $\mathrm{mL})$, and TPOAb was negative $(<0.3 \mathrm{U} / \mathrm{mL}$; reference range $\leq 6.7 \mathrm{U} / \mathrm{mL})$. TRAb was negative $(4.6 \%$, reference range $\leq 10 \%)$, and TSAb was negative $(86 \%$, reference range $<180 \%$ ). The result of the 24 -hour radioactive iodine uptake test was normal (23\%). Albumin and TBG levels were normal. When immunoglobulins were removed from the patient's serum by protein $\mathrm{A}$, $\mathrm{FT}_{4}$ and $\mathrm{TT}_{4}$ were consistently high (before treatment: $\mathrm{FT}_{4}>7.77 \mathrm{ng} / \mathrm{dL}, \mathrm{TT}_{4}>24.86 \mu \mathrm{g} / \mathrm{dL}$; after treatment: $\mathrm{FT}_{4}>7.77 \mathrm{ng} / \mathrm{dL}, \mathrm{TT}_{4}>24.86 \mu \mathrm{g} / \mathrm{dL}$ ), indicating that anti- $\mathrm{T}_{4}$ antibody did not have severe effect on these values. TSH with HAMA treatment was normal (1.17 $\mu \mathrm{U} / \mathrm{mL}$ ), suggesting that there was no effect of heterophilic antibodies, such as anti-mouse immunoglobulin, on thyroid function tests. With affinity chromatography, $\mathrm{FT}_{4}, \mathrm{TT}_{4}$, and albumin, but not $\mathrm{TBG}$, were eluted to the same fraction, and the levels of $\mathrm{FT}_{4}$ and $\mathrm{TT}_{4}$ in the fraction were extremely high in the patient's serum but not in the control serum (Fig. 1). Using a combination of reversed phase liquid chromatography and mass spectrometry techniques, amino acid sequencing of albumin protein was performed, after receiving informed consent. Sequencing coverage of albumin was almost $100 \%$, both modification of arginine 218 to proline and native sequence with arginine on position 218 was identified, and the patient was revealed to be a heterozygote for p.R218P (the normal arginine was replaced with proline) mutation in the human serum albumin. Thus, the patient was diagnosed with FDH.

Table 2 Thyroid function tests measured by different commercial kits and equilibrium dialysis

\begin{tabular}{lccc}
\hline Kit & $\mathrm{FT}_{4}(\mathrm{ng} / \mathrm{dL})$ & $\mathrm{FT}_{3}(\mathrm{pg} / \mathrm{mL})$ & $\mathrm{TSH}(\mu \mathrm{U} / \mathrm{mL})$ \\
\hline ECLusys & $>7.77$ & 8.2 & 3.74 \\
& $(0.80-1.60)$ & $(2.2-4.3)$ & $(0.20-4.50)$ \\
Lumipulse & 4.55 & 5.50 & 1.39 \\
& $(0.71-1.52)$ & $(2.39-4.06)$ & $(0.541-4.261)$ \\
Architect & $>6.00$ & 4.76 & 1.21 \\
& $(0.7-1.48)$ & $(1.71-3.71)$ & $(0.35-4.94)$ \\
Equilibrium & 2.61 & & \\
dialysis & $(0.77-1.93)$ & & \\
\hline
\end{tabular}

()$=$ reference range. $\mathrm{FT}_{3}$, free triiodothyronine; $\mathrm{FT}_{4}$, free thyroxine; TSH, thyroid-stimulating hormone. 

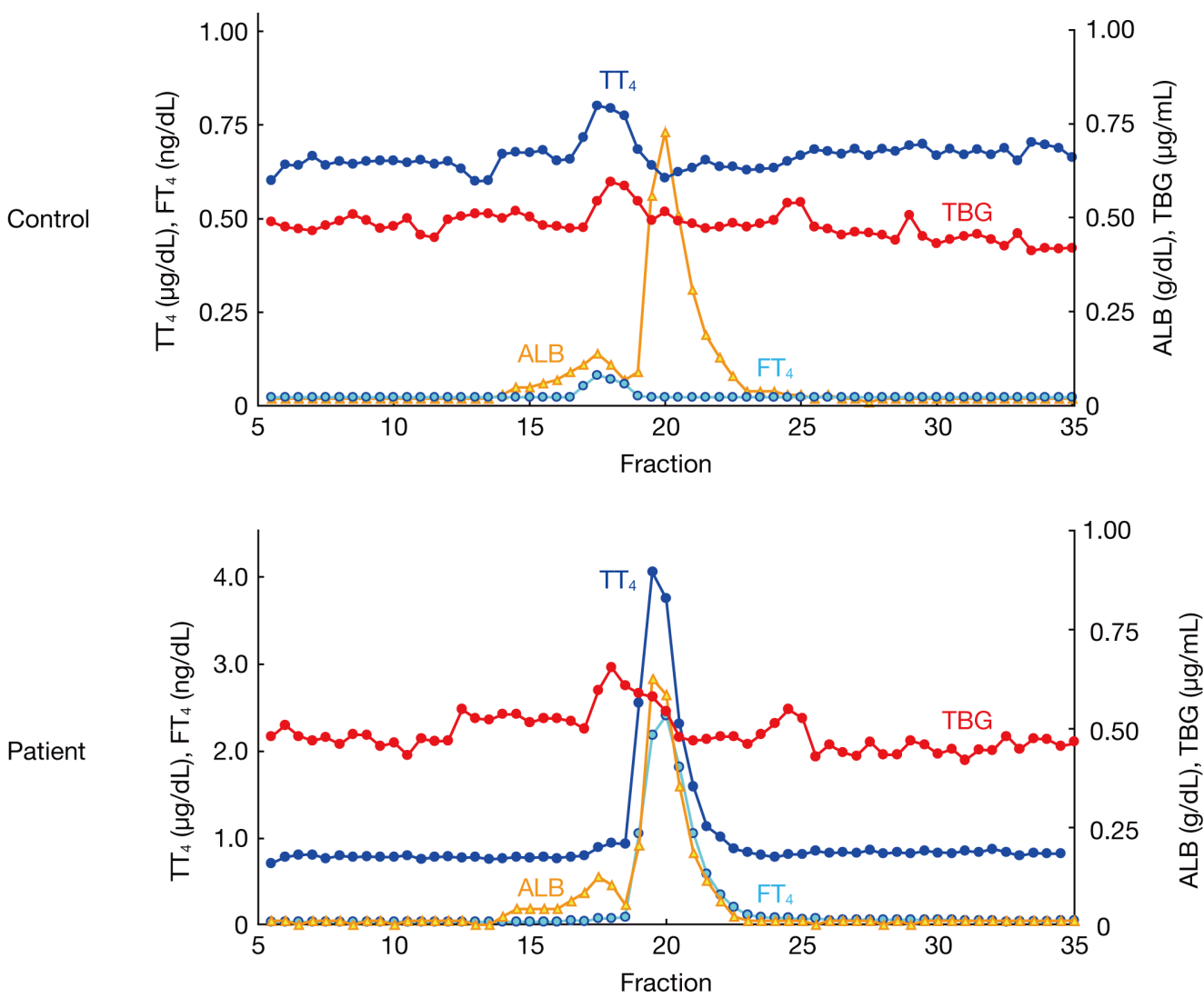

Fig. 1 Results of affinity chromatography

$\mathrm{FT}_{4}, \mathrm{TT}_{4}$, and albumin, but not $\mathrm{TBG}$, were eluted to the same fraction and the levels of $\mathrm{FT}_{4}$ and $\mathrm{TT}_{4}$ in the fraction were extremely high in the patient's serum, but not in the control serum.

\section{Discussion}

FDH is the most common inherited cause of elevated $\mathrm{TT}_{4}$ levels in euthyroid subjects and has an estimated prevalence of 1 in 10,000 Caucasian individuals [10] and 1 in 100 individuals of Hispanic origin [11]. Various mutations of the albumin gene that cause hyperthyroxinemia and/or hypertriiodothyroxinemia have been reported (Table 1). Both of p.R218P and p.R218H mutations in the albumin genes cause hyperthyroxinemia, but the p.R218P mutation in the present patient was characterized by extremely high serum $\mathrm{FT}_{4}$ levels when compared with those of patients with the p.R218H mutation. We expected that the affinity of albumin with the p.R218P mutation for $\mathrm{T}_{4}$ would be much higher than that of albumin with the $\mathrm{R} 218 \mathrm{H}$ mutation, but the affinity constants $(\mathrm{Ka})$ for mutant albumin p.R218P and p.R218H were reported to be similar [5], and recombinant p.R218H and
p.R218P had similar dissociation constants (Kd) for $\mathrm{T}_{4}$ binding [12].

Structural analysis demonstrates that residues W214, $\mathrm{R} 218$, and R222 of albumin are involved in the binding of $\mathrm{T}_{4}$. The p.R218H mutation replaces a smaller side chain at position 218 and permits a new configuration of the modified W214-H218-R222 triad that creates additional space for the ligand. The p.R218P mutation introduces an further smaller side chain at 218 , and the effect of the p.R218P mutation on the conformations of the bound $\mathrm{T}_{4}$ and the side chain of W214 and R222 is distinct from that observed for p.R218H. The differences in these protein/ligand structures may explain the different response to allosteric effectors $[12,13]$. It is reported that the chloride inhibits $\mathrm{T}_{4}$ binding to albumin and that the omission of chloride had only a slight effect on the samples from control serum but had a profound effect on the FDH samples [14]. Hoshikawa et al. speculated that $\mathrm{T}_{4}$ dissociates from the albu- 
min p.R218P during the equilibrium dialysis and that the structural change in the albumin 218P (but not in $\mathrm{R} 218 \mathrm{H}$ ) renders albumin more susceptible to the inhibitory effect of chloride ions in the dialysis buffer [15].

Fig. 1 shows two albumin peaks in both the control serum and patient serum. It is postulated that the lower peak corresponds to the albumin dimer and the higher peak corresponds to the albumin monomer. In the control serum, $\mathrm{FT}_{4}$ and $\mathrm{TT}_{4}$ peaks are located in the same fraction as the lower albumin peak, corresponding to the albumin dimer, and as one of the TBG peaks. This may be due to the binding of thyroxine to TBG, not to albumin, because $\mathrm{FT}_{4}$ and $\mathrm{T}_{4}$ peaks are not observed in the same fraction as the higher albumin peak, corresponding to the albumin monomer. In the patient serum, $\mathrm{FT}_{4}$ and $\mathrm{T}_{4}$ peaks are located in the same fraction as the higher albumin peak, corresponding to the albumin monomer. This may suggest that thyroxine binds mainly to the mutant albumin monomer in FDH. Because there is larger quantity of albumin than TBG in serum, thyroxine in the patient's serum is increased compared to thyroxine in the control serum.

The syndrome of inappropriate secretion of thyrotropin (SITSH) is a clinical condition defined as inappropriate non-suppression of serum TSH despite elevated free thyroid hormone; this condition is caused by TSH-producing pituitary adenomas (TSHomas), the syndrome of resistance to thyroid hormone (RTH) and other rare disorders [16]. FDH is one of the disorders which cause SITSH. As mentioned above, FDH has an estimated prevalence of 1 in 10,000 Caucasian individuals, however, it is extremely rare in Japan. There have been four reports of FDH in Japan $[4,15,17,18]$. So far, all of them harbored the p.R218P mutation in the albumin gene. The mutation in this case was also p.R218P. This patient was asymptomatic except for goiter, which was possibly due to anti-thyroid antibody negative Hashimoto's disease. When almost asymptomatic patients with sustained extremely high $\mathrm{FT}_{4}$ levels with unsuppressed TSH levels are found, FDH might be one of the possible differential diagnosis.

This study was limited by the fact that we could not contact the patient's family and therefore could not obtain detailed information about her family members. The only information we have received is that the patient's father was diagnosed with "thyroid disease" (not otherwise specified). This suggests that the patient's mutation was inherited rather than sporadic, but we cannot definitively confirm this notion.

In summary, this is the fifth report of FDH in the Japanese population. Although FDH is extremely rare in Japanese populations, when asymptomatic patients with sustained $\mathrm{FT}_{4}$ elevation with unsuppressed TSH are found, FDH, especially p.R218P mutation of the albumin gene, should be considered within the differential diagnosis of syndrome of inappropriate secretion of TSH (SITSH) in Japan.

\section{Disclosure}

The authors do not have any potential conflicts of interest associated with this research except for SK, who received research funding support from Chugai Pharmaceutical Co., Ltd.

\section{References}

1. Hennemann G, Docter R, Krenning EP, Bos G, Otten M, et al. (1979) Raised total thyroxine and free thyroxine index but normal free thyroxine. A serum abnormality due to inherited increased affinity of iodothyronines for serum binding protein. Lancet 1: 639-642.

2. Petersen CE, Scottolini AG, Cody LR, Mandel M, Reimer N, et al. (1994) A point mutation in the human serum albumin gene results in familial dysalbuminaemic hyperthyroxinaemia. J Med Genet 31: 355-359.

3. Sunthornthepvarakul T, Angkeow P, Weiss RE, Hayashi Y, Refetoff S (1994) An identical missense mutation in the albumin gene results in familial dysalbuminemic hyperthyroxinemia in 8 unrelated families. Biochem Biophys Res Commun 202: 781-787.

4. Wada N, Chiba H, Shimizu C, Kijima H, Kubo M, et al.
(1997) A novel missense mutation in codon 218 of the albumin gene in a distinct phenotype of familial dysalbuminemic hyperthyroxinemia in a Japanese kindred. $J$ Clin Endocrinol Metab 82: 3246-3250.

5. Pannain S, Feldman M, Eiholzer U, Weiss RE, Scherberg NH, et al. (2000) Familial dysalbuminemic hyperthyroxinemia in a Swiss family caused by a mutant albumin (R218P) shows an apparent discrepancy between serum concentration and affinity for thyroxine. J Clin Endocrinol Metab 85: 2786-2792.

6. Sunthornthepvarakul T, Likitmaskul S, Ngowngarmratana S, Angsusingha K, Kitvitayasak S, et al. (1998) Familial dysalbuminemic hypertriiodothyroninemia: a new, dominantly inherited albumin defect. J Clin Endocrinol Metab 83: 1448-1454. 
7. Greenberg SM, Ferrara AM, Nicholas ES, Dumitrescu AM, Cody V, et al. (2014) A novel mutation in the Albumin gene (R218S) causing familial dysalbuminemic hyperthyroxinemia in a family of Bangladeshi extraction. Thyroid 24: 945-950.

8. Cartwright D, O'Shea P, Rajanayagam O, Agostini M, Barker P, et al. (2009) Familial dysalbuminemic hyperthyroxinemia: a persistent diagnostic challenge. Clin Chem 55: 1044-1046.

9. Schoenmakers N, Moran C, Campi I, Agostini M, Bacon O, et al. (2014) A novel albumin gene mutation (R222I) in familial dysalbuminemic hyperthyroxinemia. J Clin Endocrinol Metab 99: E1381-1386.

10. Jensen IW, Faber J (1988) Familial dysalbuminaemic hyperthyroxinaemia: a review. J R Soc Med 81: 34-37.

11. Fisher DA, Grueters A (2008) Disorders of the thyroid in the newborn and infant. In: Sperling M (ed) Pediatric Endocrinology (3rd). Elsevier, Philadelphia, USA: 198-226.

12. Petersen CE, Ha CE, Harohalli K, Park DS, Feix JB, et al. (1999) Structural investigations of a new familial dysalbuminemic hyperthyroxinemia genotype. Clin Chem 45: 1248-1254.

13. Petitpas I, Petersen CE, Ha CE, Bhattacharya AA,
Zunszain PA, et al. (2003) Structural basis of albuminthyroxine interactions and familial dysalbuminemic hyperthyroxinemia. Proc Natl Acad Sci U S A 100: 6440-6445.

14. Ross HA, de Rijke YB, Sweep FC (2011) Spuriously High free thyroxine values in familial dysalbuminemic hyperthyroxinemia. Clin Chem 57: 524-525.

15. Hoshikawa S, Mori K, Kaise N, Nakagawa Y, Ito S, et al. (2004) Artifactually elevated serum-free thyroxine levels measured by equilibrium dialysis in a pregnant woman with familial dysalbuminemic hyperthyroxinemia. Thyroid 14: 155-160.

16. Ohba K, Noh JY, Unno T, Satoh T, Iwahara K, et al. (2012) Falsely elevated thyroid hormone levels caused by anti-ruthenium interference in the Elecsys assay resembling the syndrome of inappropriate secretion of thyrotropin. Endocr J 59: 663-667.

17. Tajima T, Jo W, Fujikura K, Fukushi M, Fujieda K (2009) Elevated free thyroxine levels detected by a neonatal screening system. Pediatr Res 66: 312-316.

18. Osaki Y, Hayashi Y, Nakagawa Y, Yoshida K, Ozaki H, et al. (2016) Familial Dysalbuminemic Hyperthyroxinemia in a Japanese Man Caused by a Point Albumin Gene Mutation (R218P). Jpn Clin Med 7: 9-13. 